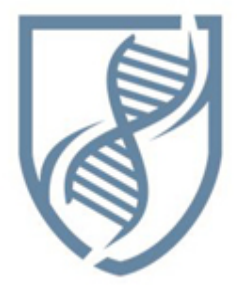

Journal of Bioscience and Applied Research

\section{JBAAR}

WWW.JBAAR.ORG

\title{
Histopathological effects of Diflubenzuron and Chromafenozide (IGRs) on egg development in the cotton leafworm Spodoptera littoralis (Boisd) (Lepidoptera, Noctuidae)
}

\author{
Ahmed, K. S.; El-Bermawy, S. M.; Ismael, E. H.; Abdel-Gawwad R. M. and Saleh, T. A.* \\ Biological and Geological Sciences Department, Faculty of Education, Ain Shams University \\ *Corresponding author: tahasaleh75@yahoo.com
}

\begin{abstract}
The present study was undertaken to investigate the possible pathogenic impacts of the $\mathrm{LC}_{50}$ of the two insect growth regulators: the chitin synthesis inhibitor, Dimilin ${ }^{\circledR}$ (Diflubenzuron), and the ecdysone agonist, Virtu ${ }^{\circledR}$ (Chromafenozide) on the ovarian tissue of adult female Spodoptera littoralis. Therefore, the $\mathrm{LC}_{50}(1.3 \& 3 \mathrm{ppm}$ of Dimilin ${ }^{\circledR}$ and $0.1 \mathrm{ppm}$ of $\left.\mathrm{Virtu}^{\circledR}\right)$ were applied to the $2^{\text {nd }}$ and $4^{\text {th }}$ larval instars, respectively. The meroistic polytrophic ovariole of $S$. littoralis is divided into a terminal filament, a germarium and a vitellarium; the germarium contains the oogonia and the follicular cells that surround the oocytes to form the ovarian follicles in the vitellarium. The ovarian follicles of treated $\mathrm{F} 1$ females with Dimilin $^{\circledR}$ exhibited vacuolization, stuffing of follicular sheath, loss of vitellin and degeneration of many cell components of follicular epithelium and oocytes. These obvious signs of damage were increased when using $4^{\text {th }}$ larval instars treatment than the $2^{\text {nd }}$.Also, damage was pronounced in the ovarioles of the $\mathrm{Virtu}^{\circledR}$ treated F1 females. Ovariole growth was stunted and vitellogenesis and chorion formation were inhibited. So, this work shows the high potency and efficacy of the two IGRs on developed ova of $S$. littoralis.
\end{abstract}

Keywords: Dimilin ${ }^{\circledR}$ diflubenzuron, Histopathology, Oogenesis, Spodoptera littoralis, Virtu ${ }^{\circledR}$ Chromafenozide.

\section{Introduction}

The cotton leafworm, S. littoralis (Boisd.) is the major pest for cotton and several important crops in Egypt causing a considerable economic loss to farmers every year (Hosny et al., 1986). Control programs of S. littoralis depends mainly on the use of various conventional insecticides that, in turn, has given rise to many problems as residual toxicity and pollution, pest resistance development, outbreaks of secondary pests and harmful effects on beneficial species (Forgash, 1984 \& Georghiou, 1986). S. littoralis has acquired resistance to different insecticides commonly used in Egypt throughout chemical control programs used on various crops (El-Guindy,et al., 1982 and 1989; El-Baramawy et al., 1991). Insect growth regulators (IGRs) are diverse groups of chemical compounds that are highly active against immature stage of insects and have a good margin of safety to most non-target biota including invertebrates, fishes, birds and other wild life; they are also safe to human and domestic animals. They play an important role in control programs now and coming days (Mulla, 1995 and Darvas, and Polgar, 1998). The main types of insect growth regulators used commercially are juvenile hormone analogues and chitin synthesis inhibitors (Parrella and Murphy, 1998). Dimilin ${ }^{\circledR}$ interferes with chitin synthesis in insects and kills their immature stages by disrupting their growth (Gijswijt, et al., 1979; Hammock and Quistad, 1981; Tripathi, 1996; Anwar and Abd El-Mageed, 2005; Abdel Rahman et al.,2007), high destructions in fibrous ovariole membranes (AbdelGhany et al., 1985), decreases thickness of the follicular epithelium and reduces protein content and number of oocytes per ovary (Soltani and Soltani-Mazouni, 1992). Virtu $^{\circledR}$, non-steroidal moulting hormone agonists, has insecticidal activity by disrupting insect moulting. So, it is very potent against Lepidoptera, but weak or inactive against other insect orders such as Diptera and Coleoptera (Nakagawa et al. 2005). Also, the use of chromafenozide at recommended dose did not pose any hazards to consumers when applied in strawberry under open field conditions (Malhat et al. 2014). Insect ovary, due to its essential role in insect reproduction, has been a perennial 
topic of investigation. Its scope has dramatically increased during the last decades (Boning 1998). Shalaby et al. (1987) postulated that the application of juvenoid ZR-520 reduced number of oocytes and caused variation in their sizes and shapes and difficultly to distinguish between oocytes and nurse cells in S. littoralis. In 2000, Sorge et al. suggested that a crucial role for ecdysone agonist, 20hydroxyecdysone, in the induction of vitellogenesis in the noctuid $S$. frugiperda, and may trigger biosynthesis in the ovary. Histological studies of gonads may provide morphological evidence for functions of gonial, extragonial tissues and cells (Bakr et al. 2010).

The aim of the present study is to examine the histopathological changes occurred in the ovaries of the $S$. littoralis developed from treated $2^{\text {nd }}$ and $4^{\text {th }}$ larval instars with $\left(\mathrm{LC}_{50}\right)$ of these two insect growth regulators; Dimilin ${ }^{\circledR}$ and Virtu ${ }^{\circledR}$.

\section{Materials and Methods}

\section{Insect culture:}

The stock colony of S. littoralis was obtained from Plant Protection Research Institute, Agricultural Research Center, Dokki, Giza. This strain was reared under the technique described by El-Defrawy et al. 1964. Larvae were provided daily with fresh castor bean leaves Ricinus communis. The number of larvae per jar was gradually decreased as the larvae developed reaching twenty per jar for the $6^{\text {th }}$ instar. The jars were incubated in the laboratory under constant laboratory conditions of $27 \pm 2{ }^{\circ} \mathrm{C}$ and $65 \pm 5$ $\%$ RH. The resulting moths were fed on $20 \%$ sugar solution and allowed to lay their eggs on fresh Nerium oleader leaves as a physical surface for moths mating. Egg patches were collected daily and transferred into petri dishes until hatching.

\section{Insect growth regulators used:}

Two analogues of insect growth regulators (IGRs) were used:

1-Diflubenzuron (Product name: Dimilin ${ }^{\circledR} 48 \%$ SC) is a benzamide insecticide Diflubenzuron, insecticide against lepidopteran larvae, was discovered and developed under cooperative works by Chemtura Co., Ltd. USA.

Dimilin $^{\circledR}$ (Diflubenzuron): N-[[(4-chlorophenyl)amino] carbonyl]-2,6-difluorobenzamide or 1-(4-chlorophenyl)-3(2,6- difluorobenzoyl)urea.

2-Chromafenozide (Product name: Virtu ${ }^{\circledR} \mathbf{5 \%}$ ) is a novel non-steroidal agonist of the insect moulting hormone 20hydroxyecdysone.Chromafenozide, insecticide against lepidopteran larvae, was discovered and developed under cooperative works by Nippon Kayaku Co., Ltd. and Sankyo Co., Ltd. Japan.

Virtu $^{\circledR} \quad$ (Chromafenozide):3,4-dihydro-5-methyl-2H-1benzopyran-6-carboxylic acid 2-(3,5-dimethylbenzoyl)-2(1,1-dimethylethyl) hydrazide.

\section{Bioassay:}

Six concentrations of $\operatorname{Dimilin}^{\circledR}(0.1,0.5,1,2,4$ and 10 ppm) and $\left(0.001,0.01,0.1,0.5,1\right.$ and 2 ppm) of Virtu ${ }^{\circledR}$ were prepared. The treatment was done by dipping castor oil leaves in appropriate concentrations for 1 minute. The tested leaves were allowed to dry and affected to the $2^{\text {nd }}$ and $4^{\text {th }}$ larval instar larvae for 24 hours and then replaced by untreated leaves. The larvae fed on untreated leaves served as control until population. Three replicates of 20 larvae were used in each concentration. All mortality observations were corrected by Abbott's formula (1925) and subjected to probity analysis by Finney (1971) to calculate the LC50 (Tab.1 \& Fig.1).

\section{Table (1): preliminary tests for $\mathrm{LC}_{50}$ detection}

\begin{tabular}{|c|c|c|c|c|}
\hline \multicolumn{5}{|c|}{ (a) Preliminary tests for detection of the LC $\mathbf{C}_{\mathbf{5 0}}$ of Dimilin (second larval instar) } \\
\hline (ppm) & $\begin{array}{c}\text { Total number } \\
\text { of insects } \\
\text { tested }\end{array}$ & $\begin{array}{c}\text { Dead larvae } \\
\text { after } \\
24 \text { hours }\end{array}$ & Observed mortility \% & $\begin{array}{c}\text { Corrected mortility } \% \\
\text { according to Abbott's } \\
\text { Formula }\end{array}$ \\
\hline $\mathbf{0 . 1}$ & 60 & 11 & $18.33 \%$ & $15.01 \%$ \\
\hline $\mathbf{0 . 5}$ & 60 & 21 & $35.00 \%$ & $31.68 \%$ \\
\hline $\mathbf{1}$ & 60 & 30 & $50.00 \%$ & $46.68 \%$ \\
\hline $\mathbf{2}$ & 60 & 37 & $61.67 \%$ & $58.35 \%$ \\
\hline $\mathbf{4}$ & 60 & 49 & $81.67 \%$ & $78.36 \%$ \\
\hline $\mathbf{1 0}$ & 60 & 59 & $98.33 \%$ & $95.03 \%$ \\
\hline Control & 60 & 2 & $3.33 \%$ & $0.00 \%$ \\
\hline
\end{tabular}

(b) Preliminary tests for detection of the $\mathrm{LC}_{50}$ of Dimilin (fourth larval instar)

\begin{tabular}{|c|c|c|c|c|}
\hline (ppm) & $\begin{array}{c}\text { Total number } \\
\text { of insects } \\
\text { tested }\end{array}$ & $\begin{array}{c}\text { Dead larvae } \\
\text { after } \\
\text { 24 hours }\end{array}$ & Observed mortility \% & $\begin{array}{c}\text { Corrected mortility } \% \\
\text { according to Abbots } \\
\text { Formula }\end{array}$ \\
\hline $\mathbf{0 . 5}$ & 60 & 15 & $25.00 \%$ & $11.68 \%$ \\
\hline $\mathbf{1}$ & 60 & 25 & $41.67 \%$ & $28.37 \%$ \\
\hline $\mathbf{2}$ & 60 & 34 & $56.67 \%$ & $43.39 \%$ \\
\hline $\mathbf{4}$ & 60 & 50 & $83.33 \%$ & $70.09 \%$ \\
\hline $\mathbf{1 0}$ & 60 & 57 & $95.00 \%$ & $81.78 \%$ \\
\hline $\mathbf{2 0}$ & 60 & 59 & $98.33 \%$ & $85.11 \%$ \\
\hline Control & 60 & 8 & $13.33 \%$ & $0.00 \%$ \\
\hline
\end{tabular}

(c) Preliminary tests for detection of the $\mathrm{LC}_{50}$ of Virtu (second larval instar)

\begin{tabular}{|c|c|c|c|c|}
\hline (ppm) & $\begin{array}{c}\text { Total number } \\
\text { of insects } \\
\text { tested }\end{array}$ & $\begin{array}{c}\text { Dead larvae } \\
\text { after } \\
24 \text { hours }\end{array}$ & Observed mortility \% & $\begin{array}{c}\text { Corrected mortility \% } \\
\text { according to Abbotts } \\
\text { Formula }\end{array}$ \\
\hline $\mathbf{0 . 0 0 1}$ & 60 & 11 & $18.33 \%$ & $6.67 \%$ \\
\hline $\mathbf{0 . 0 1}$ & 60 & 20 & $33.33 \%$ & $21.69 \%$ \\
\hline $\mathbf{0 . 1}$ & 60 & 37 & $61.67 \%$ & $50.06 \%$ \\
\hline $\mathbf{0 . 5}$ & 60 & 49 & $81.67 \%$ & $70.08 \%$ \\
\hline $\mathbf{1}$ & 60 & 55 & $91.67 \%$ & $80.09 \%$ \\
\hline $\mathbf{2}$ & 60 & 60 & $100.00 \%$ & $88.44 \%$ \\
\hline Controls & 60 & 7 & $11.67 \%$ & $0.00 \%$ \\
\hline
\end{tabular}

(d) Preliminary tests for detection of the $\mathrm{LC}_{50}$ of Virtu (fourth larval instar)

\begin{tabular}{|c|c|c|c|c|}
\hline (ppm) & $\begin{array}{c}\text { Total number } \\
\text { of insects } \\
\text { tested }\end{array}$ & $\begin{array}{c}\text { Dead larvae } \\
\text { after } \\
24 \text { hours }\end{array}$ & Observed mortility \% & $\begin{array}{c}\text { Corrected mortility \% } \\
\text { according to Abbott's } \\
\text { Formula }\end{array}$ \\
\hline $\mathbf{0 . 0 0 1}$ & 60 & 11 & $18.33 \%$ & $1.67 \%$ \\
\hline $\mathbf{0 . 0 1}$ & 60 & 25 & $41.67 \%$ & $25.04 \%$ \\
\hline $\mathbf{0 . 1}$ & 60 & 40 & $66.67 \%$ & $50.08 \%$ \\
\hline $\mathbf{0 . 5}$ & 60 & 53 & $88.33 \%$ & $71.79 \%$ \\
\hline $\mathbf{1}$ & 60 & 58 & $96.67 \%$ & $80.13 \%$ \\
\hline $\mathbf{2}$ & 60 & 58 & $96.67 \%$ & $80.13 \%$ \\
\hline Controls & 60 & 10 & $16.67 \%$ & $0.00 \%$ \\
\hline
\end{tabular}

\section{Histological study:}

The $2^{\text {nd }}$ and $4^{\text {th }}$ larval instars of S. littoralis were treated with the estimated $\mathrm{LC}_{50}$ of Dimilin ${ }^{\circledR}$ and Virtu ${ }^{\circledR}$ for 24 hours. The living individuals reared till adults emerge which were studied as treated group. The ovaries of the control and treated F1 females were dissected in Ringer's saline solution. These ovaries were used for histological study using the light microscope. Bouin`s fluid was used to fix the female reproductive organs. The ovaries were then dehydrated in series of ethanol. Then cleared in xylene and embedded in paraffin wax. Serial sections, $5 \mathrm{~m}$ thick, were cut, stained with haematoxylin and eosin, then cleared and mounted in DPX. 

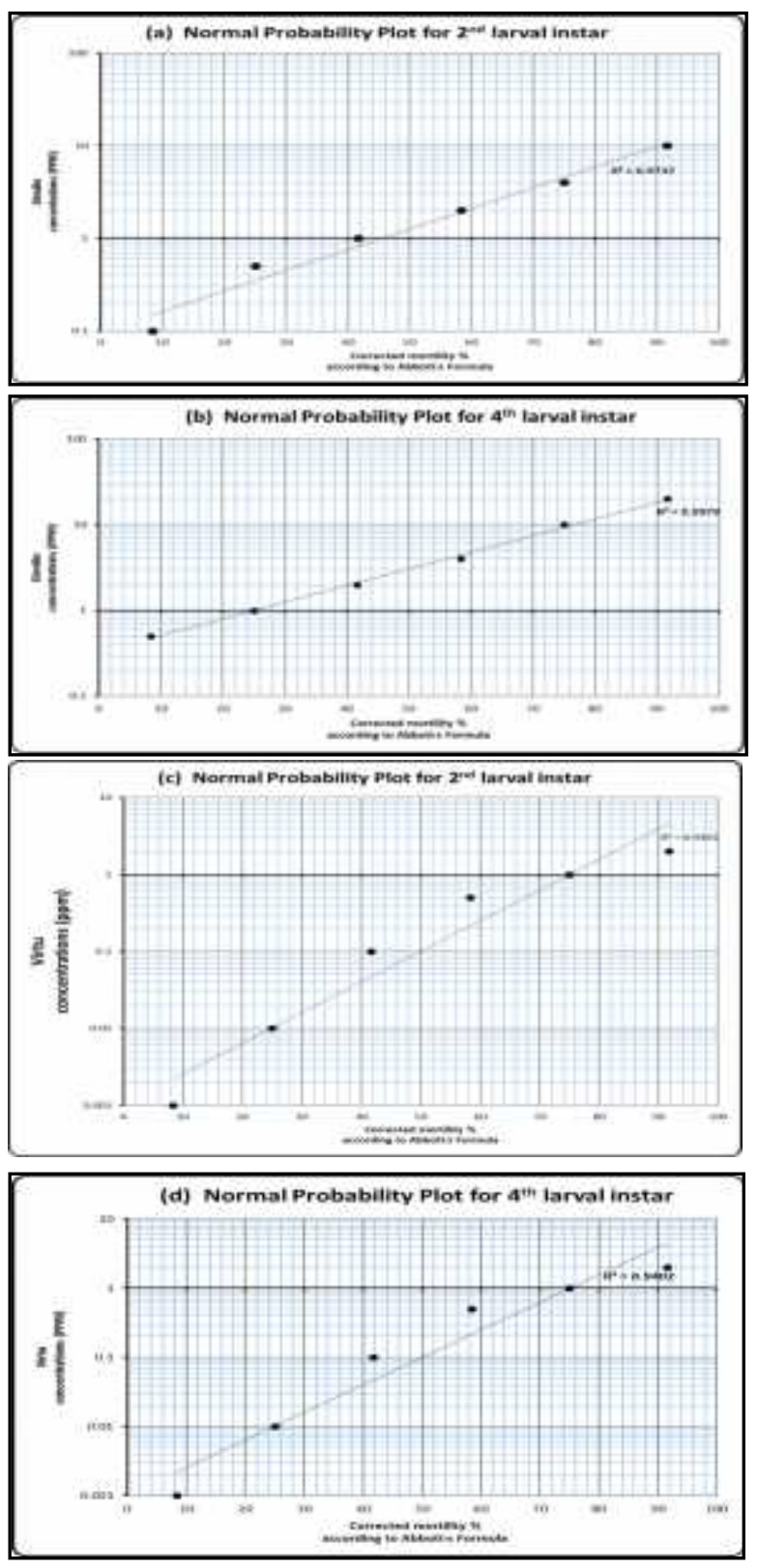

Fig. (1): Normal plots for $\mathrm{LC}_{50}$ detection

\section{Results}

The female reproductive system of cotton leafworm, S. littoralis (Boisd.) composed of a pair of ovaries of the meroisticpolytrophic type. Each of which consists of four elongated functional units (termed the ovarioles) where the ova are actually produced. As a rule, individual ovariole comprises four easily recognizable regions: a terminal filament, germarium, vitellarium and an ovariole pedicel connecting the ovariole to the lateral oviduct. Near the distal end (the terminal filament) of ovariole, there are groups of germ cells, oogonia, which divide by mitosis and increase in size to form oocytes. Each oocyte undergoes meiosis: this yields four cells, one egg and three polar bodies that may disintegrate or they may accompany the egg as trophocytes. The normal ovariole contained a chain of developing ova which had defined spherical shape. The oocyte enclosed with follicular cells. The oocytes had well differentiated and branched nuclei contained dispersed chromatin granules. In addition, the trophocytes or nurse cells supplied growing oocytes with nutrients. The follicle cells surround the oocytes forming the follicular epithelium. In order for vitellogenin $(\mathrm{Vg})$ to enter the oocyte, intercellular follicular spaces are formed, a process called patency, which is induced by $\mathrm{JH}$. As the $\mathrm{Vg}$ enters the oocyte it converted to vitellin $(\mathrm{Vn})$; which is one main components of yolk, used by the embryo, and is surrounding the nucleus and replacing the cytoplasm. The nurse cells provide the developing egg with nursing materials, while the cells surrounding oocyte, follicle cells, assist in producing the egg membranes (Fig.2).

Group (I); Ovariole structure of control moth: Light microscopic examination of the ovarioles of control moths showed that each ovariole is composed of the terminal filaments, followed by the germarium with mast cells and profollicles (Fig. 2a). The latter contains trophocytes nurse cells - and follicular epithelial layer (Fig. 2b). Trophocytes characterized by their peculiar nuclei (Fig. $2 c)$. As seen in figure(2d-f), the ovarian follicle of vitellogenic ovariole composed of one oocyte occupying the lumen with the vitellin nutrients, the trophocytes (nurse cells) exhibited in the anterior pole and an outer follicular epithelial layer.

Group (II); adult ovariolestructure oftreated larvae with LC50of Dimilin $®$ : At the histological level, treatment with LC50 (1.3 \& 3 ppm) of Dimilin ${ }^{\circledR}$ for 2 nd and 4th larval instars respectively, induced advanced signs of damage in the ovariolestissue (Figs. 3\&4). The Dimilin ${ }^{\circledR}$ caused histopathological changes in both germarium and vitellarium regions of the ovarioles. Most of the follicular oocytes appeared with altered structure. The treated 2nd larval instars with LC50 (1.3 ppm), as seen in figures(3a$3 \mathrm{~d}$ ), showing the follicular oocytes revealed signs of damage among ovarian tissue. A marked increase in the number of the vacuoles was observed in the cytoplasm of the oocytes. The nuclei of some follicular cells revealed clumps of highly condensed nuclear material that represented signs of pyknosis as demonstrated in these figures. In addition, the follicular sheath was irregular in shape and discontinued in many positions. The treated4th larvalinstars with LC50 (3 ppm), figures $4 \mathrm{a}-4 \mathrm{~d}$, revealed different profiles of vitellin degeneration as a result of degenerated follicular epithelium and that dramatically lead to chorion formation failure.

Group (III); adult ovariole structure of treated larvae with LC50 of Virtu ${ }^{\circledR}$ : The ovarioles of such moths revealed marked histopathological changes in the vitellarium and its boundary tissue (Figs. 5-6). Figures (5a-5d) revealed that effect when using $2^{\text {nd }}$ larval instar while figures (6a-6d) represented the effect as a result of treating $4^{\text {th }}$ larval instar. The boundary tissue exhibited prominent degenerations. It was folded and got thickened (Figs. 5a\&6b). Their nuclei showed progressive signs of pyknosis and variable signs of damage. Separation of outer and inner follicular membrane also noted in all cases leading to inhibition of chorion formation. Follicular oocytes showed progressive signs of necrosis. Figures (5a, 6a-6d) revealed irregular oocytes with separation of follicular epithelium. Also, obvious shrunk of follicular oocytes were seen and their cytoplasm exhibited large number of vacuoles of different sizes, 

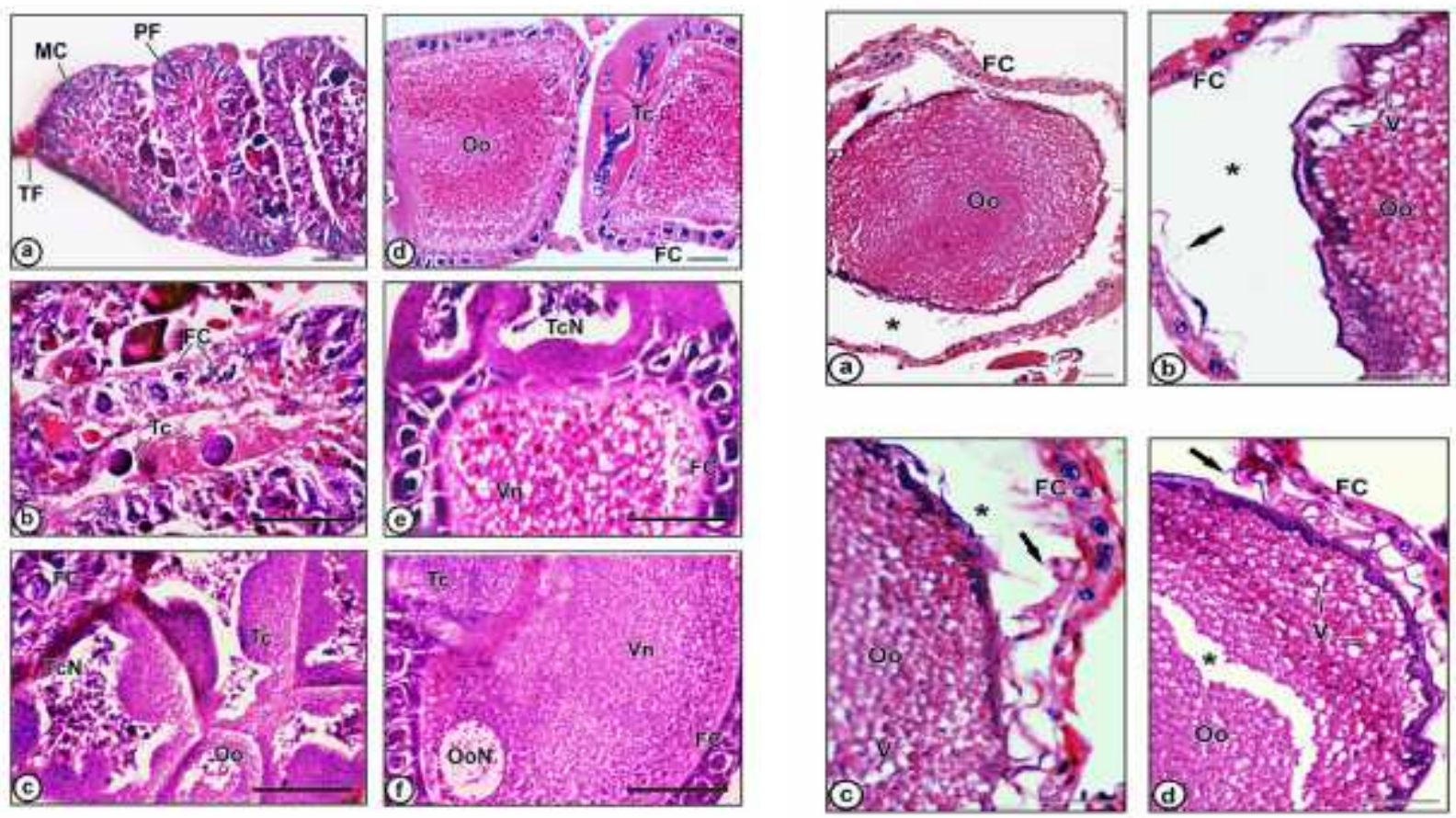

Fig. (2): Photomicrographs of ovarioles of control moths

$($ Scale bar $=50 \mu \mathrm{m})$

(a): Showing general structure of the germarium. Notice the terminal filament (TF) followed by mast cells (MC) and successive pro-follicle cells (PF).

(b): Showing trophocytes (Tc) and surrounded by follicular cells. Notice trophocytes nuclei (TC).

(c): Showing developing oocyte (Oo) surrounded by follicular cells (FC). The trophocytes are having irregular nuclei ( $\mathrm{TcN})$.

(d): The growing follicle containing oocyte (Oo) with yolk molecules, trophocytes (Tc) and follicular cells (FC).

(e): A magnified growing follicle showing trophocytes with their peculiar nuclei $(\mathrm{TcN})$, oocyte containing the vitellin $(\mathrm{Vn})$ and yolk molecules and follicular epithelium including follicular cells (FC). (f): Showing trophocyte (Tc), oocyte with its nucleus $(\mathrm{OoN})$ and vitellin granules $(\mathrm{Vn})$ and are surrounded by epithelial follicular cells

Fig. (3): Photomicrographs of moth ovariole from treated $2^{\text {nd }}$ larval instars with $\mathbf{L C}_{\mathbf{5 0}}(\mathbf{1 . 3} \mathrm{ppm})$ of Dimilin $^{\circledR}$ (Scale bar $=$ $50 \mu \mathrm{m})$

(a): Degenerated oocyte (Oo) with separated epithelial follicular cells (FC). Large space (*) among mature follicle is also observed. (b): Another deteriorated oocyte (Oo) with variable vacuoles $(\mathrm{V})$. Note also the basement membrane separation (arrows) from follicular cells (FC). Large space $(*)$ between oocyte and follicular cells is obviously seen.

(c): Oocyte cytoplasm (Oo) with different vacuoles (V). The follicular epithelium $(\mathrm{Fc})$ is seen folded (arrow) with pyknotic nuclei. Obvious separation of follicular cell membrane is also noticed.

(d): Another degenerated oocyte (Oo) with different vacuoles (V). A great separation among cytoplasm of oocyte is recorded (*). In addition, a marked separation and folding (arrow) of inner epithelial membrane of follicular cells (FC) with pyknotic nuclei are seen also. 

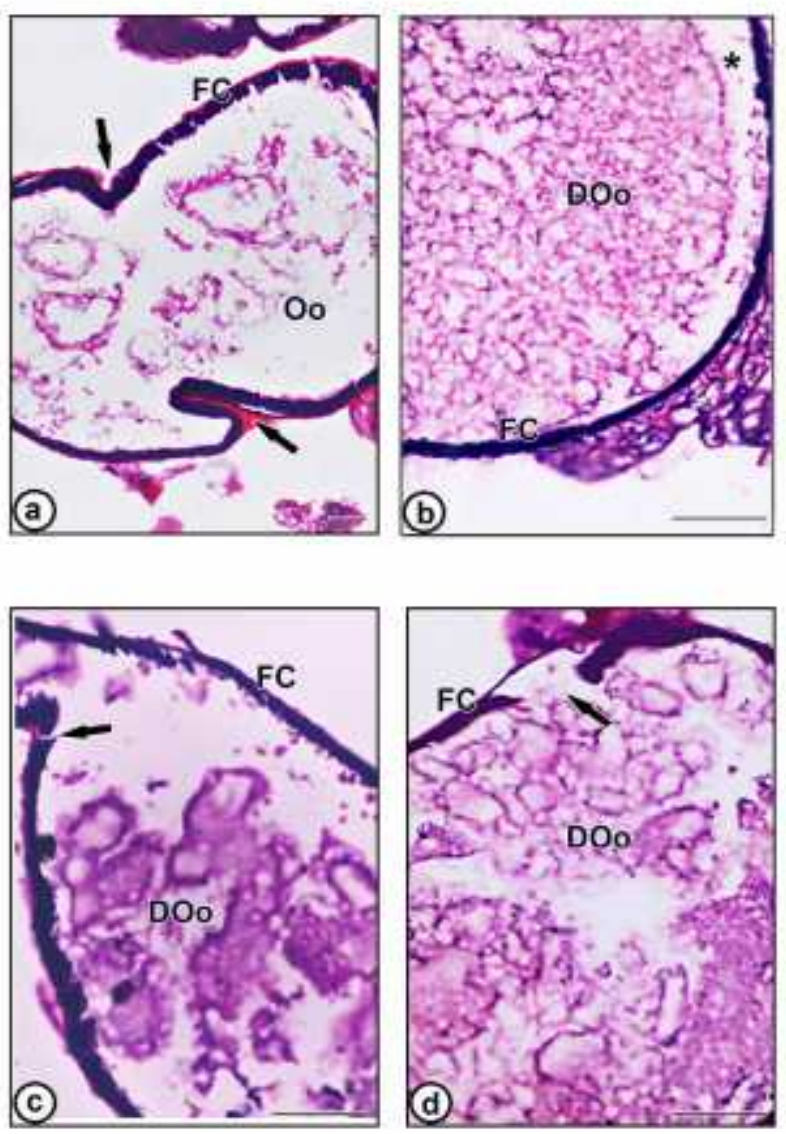

Fig. (4): Photomicrographs of moth ovariole sections of treated $4^{\text {th }}$ larval instars with LC $_{50}(3 \mathrm{ppm})$ Dimilin $^{\circledR}$ (Scale bar $=50 \mu \mathrm{m})$

(a): Degenerated oocyte (Oo) with failed vitellogenesis. Moreover, follicular cells (FC) appeared infolded (arrow) and their nuclei are suffering from pyknosis.

(b): Another deteriorated oocyte (DOo) with follicular cells (FC) thickening. Note also pyknotic follicular cells nuclei.

(c): Deformed oocyte (DOo) with loss of vitellin. The surrounded thickening follicular cells (FC) appeared with pyknotic nuclei. Note also the deformation of follicular membranes (arrow).

(d): Another magnified part of deformed oocyte (Doo) with sings of necrosis. Its cytoplasm showing failed vitellogenesis. In addition, follicular cells (FC) are suffering from separation (arrow) and their nuclei appeared pyknotic.
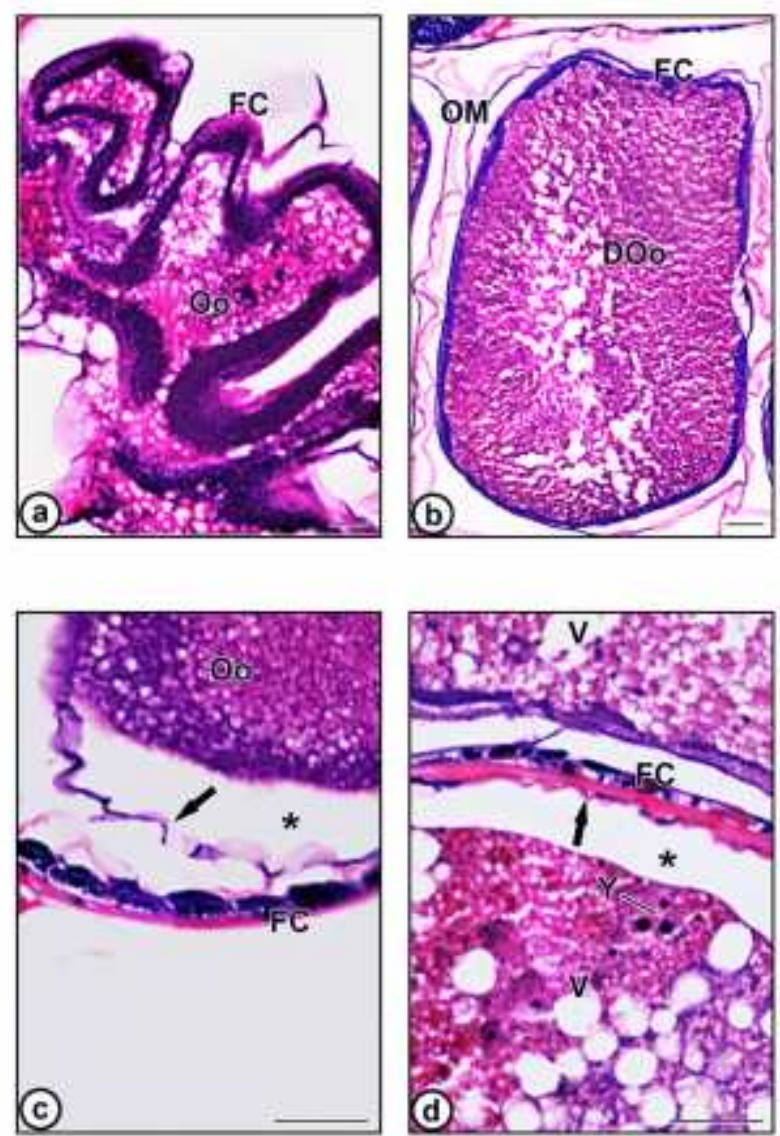

Fig. (5): Photomicrographs of moth ovarioles sections of treated $2^{\text {nd }}$ larval instars withLC $C_{50}(0.1 p p m)$ Virtu ${ }^{\circledR}($ Scale bar $=$ $50 \mu \mathrm{m})$

(a): Degenerated irregular oocytes (Oo) with great number of vacuoles (V). Thickening of epithelial follicular cells (FC) with separation of epithelial membranes are also seen.

(b): Another deformed oocyte (DOo) with many vacuoles. Note also the separation of outer $(\mathrm{OM})$ and inner membranes of follicular cells (FC).

(c): A magnified part of the oocyte (Oo) showing the deformed vitellin in cytoplasm. Also, there is wide separation (*) between oocyte and surrounding follicular cells (FC). The later has pyknotic nuclei and separated inner membrane (arrow).

(d): Two neighboring follicle oocytes (Oo) with great number of deferent vacuoles (V) are seen. Note the lipolysis of their vitellin contents leaving them vacuolated. In addition, follicular cells (FC) have pyknotic nuclei and their inner membrane becomes wavy (arrow) leaving large space $(*)$ between follicular cells and oocyte. 
degenerated yolk granules. Furthermore, wide spread cytolysis is observed in the oocyte follicles (Figs. 5a, 5b, $6 a \& 6 b)$.
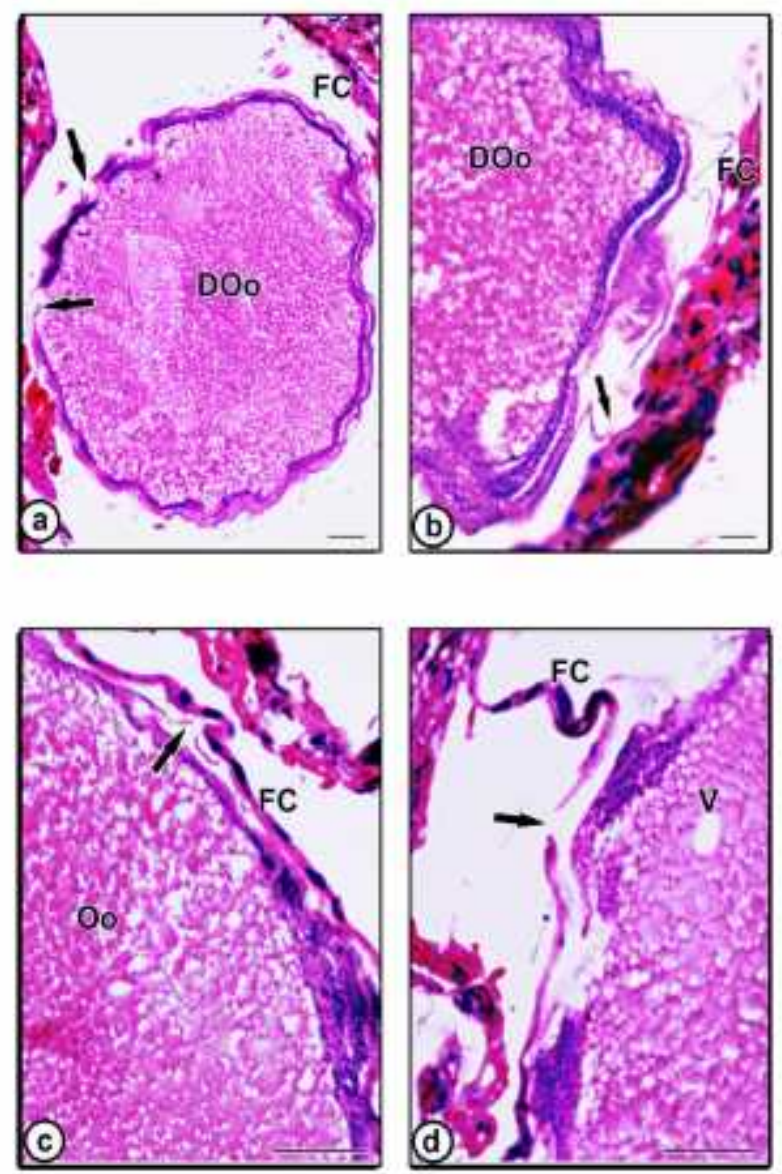

Fig. (6): Photomicrographs of ovariole moths sections of treated $4^{\text {th }}$ larval instars withLC $C_{50}(0.1 \mathrm{ppm})$ Virtu $^{\circledR}$ (Scale bar $=50 \mu \mathrm{m})$

(a): Another sign of deformed oocyte (Oo) with great separation between oocyte and follicular cells (FC). Note the breakage of follicular epithelium (arrow) with wavy shape.

(b): Another sing of oocyte deformation (DOo) with thickening follicular cells (FC) and separation of inner membrane (arrow).

(c): The developing oocyte $(\mathrm{Oo})$ in particular stage of growth surrounded by deformed follicular cells (FC) with pyknotic nuclei and irregular separated inner membrane (arrow).

(d): The follicular oocyte containing vacuoles (V) and discontinued (arrow) and wavy follicular cells (FC).

\section{References}

Abbott, W. S. (1925). A method of computing the effectiveness of an insecticide. J. Econ. Eotomol., 18: 265267.

Abdel- Rahman, S. M.; Hegazy, E. M. and Elwey, A. E. (2007). Direct and latent effects of two chitin synthesis inhibitors to Spodoptera littoralis larvae (Boisd). Am. Eurasian J. Agric. Environ. Sci., 2(4): 457-467.

\section{Discussion}

Insect ovariole is considered to be the most important organ in the female reproductive system. It is the site where oogenesis takes place. Various factors could affect oogenesis; among these factors are chemical agents such as insecticides and IGRs. At histological level, the present work demonstrated that many histopathological changes in ovarioles of adult females S. littoralis were produced by treating the 2nd and 4th larval instars with the IGRs Dimilin ${ }^{\circledR}$ and Virtu ${ }^{\circledR}$, each at LC50. The treatment induced disturbance in protein synthesis of the ovarioles which reflect an inhibition of ovariole maturation (Saini et al. 2010). From the present observations, the follicular cells are suffering from degeneration and vacuolation. Follicular cells apparently regulate transfer of materials for oocyte growth. The use of IGRs retarded the oogenesis in treated larvae. In 1979, Rey and Ramamurty on their histochemical studies on the telotrophic ovarioles of Crynodes peregrinus explored that the follicle cells synthesize RNA which is exported to oocytes during its early stages of growth. Our findings are similar to those observed by (Lim and Lee, 1982) who reported that diflubenzuron (DFB) retard the maturation of oocytes when applied against grasshopper, Oxya japanica. In addition, the follicular epithelium surrounding the vitellogenic oocytes of Locusta migratoria, developed large spaces between the cells when ovary was exposed to methoprene (Davey et al. 1993). According to Tanaka et al. (1998), the juvenile hormone analogue, methoprene, applied to Locusta migratoria stimulated oocytes development in reproductively inactive females. Nevertheless, fenoxycarb application against the newly emerged adults of xenopsylla cheopis stimulated ovarian cells to be atrophied (Zhang and Qi, 2008). Furthermore, Bakr et al., (2010) displayed that IGRs Consult and Lufox stimulated vacuolization of cytoplasm and degeneration of the cell components of follicular epithelium in the desert locust. Moreover, the species-specific ecdysone-agonistbased insecticides can be developed, but their species specificity is not based on differences in the activation of the ecdysone receptor but rather on unidentified in vivo parameters such as permeability of the cuticle, uptake/excretion by the gut or metabolic detoxification (Soin et al., 2010). As shown in the present study, the previous findings support the idea that the modified follicular epithelium and deformed vitellogenic oocytes could induce disturbances in oogenesis which led to degrees of chorion formation inhibition and fecundity reduction.

Abdel-Ghany, A. A., Negm, S. E. and Saleh, A. A. (1985). Changes in development of reproductive organs of Spodoptera littoralis (Boisd.) caused by insect growth regulators. J. Agric. Mansura Univ., 10(1): 296-305.

Anwar, E. M. and Abd El-mageed, A. E. M. (2005). Toxicity impacts of certain insect growth regulators on some biochemical activities of the cotton leafworm. Egypt. J. Agric. Res., 83(3):915-935. 
Bakr, R. F. A., Mohammed, M. I., El-Gammal, A. M. and Mahdy, N. M. (2010). Histopathological alteration in the ovaries of the desert locust Schistocerca gregaria (Forskal) induced by the IGR Consult and Lufox. Egypt. Acad. J. biolog. Sci., 1(1): 1-6.

Boning, J. (1998). The insect ovary. Ultra-structure, previtellogenic growth and evolution. Eur. J. Entomol., 95: 34.

Darvas, B. and Polgar, L. A., (1998). Novel type insecticides: specificity and effects on non-target organisms. In: Ishaaya, I., Degheele, D. (Eds.), Insecticides with Novel Modes of Action. Springer, Berlin, pp. 188-259.

Davey, K. J., Sevala, V. L. and Gordon, D. R. B. T. (1993). The action of juvenile hormone and
antigonadotropic on the follicle cells of Locusta migratoria. Invert. Reprod. Develop., 24(1): 39-45.

El-Baramawy, Z. A., Elshikh, A. A., Rashwan, M. H. and Radwan, H. S. A. (1991). Pyrthroids resistance in Spodoptera littoralis (Boisd.), (Lepidoptera Noctuidae) in Lower Egypt. Bull. Ent. Soc. Egypt. Econ. Ser., 19: 41-51.

El-Defrawy, M.; Toppozada, A., Mansour, N. and Zeid, M. (1964). Toxicological studies on the Egyptian cotton leaf worm, Prodenia litura 1. Susceptibility of different larval instars to insecticides. J. Econ. Entomol., 57: 591-593.

El-Guindy, M. A., Keddis, N. E., Abd El-Satter, M. M. and Ghonieim, Y.A. (1989). Status of resistance to pesticides in the cotton leaf worm Spodoptera littoralis (Boisd.), under the present Egyptian cotton pest control programme. Proc. 1st Int. Conf. Ent., (11): 453-462.

El-Guindy, M. A., Madi, S. M., Keddis, M. E., Issa, Y. H. and Abd El-Satter, M. M. (1982). Development of resistance to pyrthroides in field population of the Egyptian cotton leaf worm Spodoptera littoralis (Boisd.). Int. Pest. Cont., 24: 6-10.

Finney, D. J. (1971). Probit analysis, 3rd ed. Cambridge university press, LondonJ. of Pharma. Sci., 60(9): pp: 1432.

Forgash, A. J. (1984). History evolution and consequences of insecticide re-sistance. Pestic. Biochem. Physiol., 22:178-186.

Georghiou, G. P. (1986). The magnitude of the resistance problem. p. 14-43. In: Pesticide Resistance: Strategies and Tactics for Management. National Academy Press, Washington, D.C.

Gijswijt, M. J., Deul, D. H. and Dejong, B. J. (1979). Inhibition of chitin synthesis by benzoylphenylurea insecticides, III. Similarity in action in Pieres brassicae (L.) with polyxin D. Pestic. Biochem. Physiol., 12:84-94.

Hammock, B. D. and Quistad, G. B. (1981). Metabolism and mode of action of juvenile hormone, Juveno-ids and other insect growth regula-tors, in the Juvenile hormone. (Ed. L. I. Gilbert) PP: 374-394 Plenum press New York.

Hosny, M. M., Topper, C. P., Moawad, G. G. and ElSaadany, G. B. (1986). Economic damage thresholds of Spodoptera littoralis (Boisd.) (Lepidoptera: Noctuidae) on cotton in Egypt. Crop Prot.; 5:100-104.
Lim, S. J. and Lee, S. S. (1982). Toxicity of diflubenzuron to the grasshopper Oxya japonica: effects on reproduction. Entomologia Expermentalis et Applicata. 31(2-3): 154-158.

Malhat, F., Badawy, H. M.A., Barakat, D. A. and Saber, A. N. (2014). Residues, dissipation and safety evaluation of chromafenozide in strawberry under open field conditions. Food Chem., 152(1): 18-22.

Mulla, M. S. (1995). The future of insect growth regulators in vector control. J. Am. Mosq. Control. Assoc., 11(2): 269-273.

Nakagawa, Y., Takahashi, K., Kishikawa, H.; Ogura, T., Minakuchi, C., and Miyagawa, H. (2005). Classical and three-dimensional QSAR for the inhibition of $[3 \mathrm{H}]$ ponasterone A binding by diacylhydrazine-type ecdysone agonists to insect Sf-9 cells. Bioorganic \& Medicinal Chem. 13: 1333-1340.

Parrella, M. P. and Murphy, B. C. (1998). Insect growth regulators. Growers Talke, 62(2): 86-89.

Rey, A. and Ramamurty, P. S. (1979). Source of RNA Supply to oocytes in Crynodes peregrinus fuessly (Coleoptera, chrysomedidac). Int. J. Insect Morphol. and Embryol., 8(2): 113-122.

Saini, R. K., Pala, R. and Saharan, H. S. (2010). Bioefficacy of chromafenozide (Matric 80 WP) against Spodoptera litura (Fab.) on cotton. Journal of Cotton Research and Development, 24(2): 221-224.

Shalaby, A. M., El-Zayat, M. A., Hasem, H. O. and Swidan, M. H. (1987). Effect of the juvenoid ZR-520 on the ovarian development of Spodoptera littoralis (Boisd.). Bull. Fac. Sci. Alex. Univ., 27(4A): 141-156.

Soin, T., De Geyter, E., Mosallanejad, H., Iga, M., Martín, D., Ozaki, S., Kitsuda, S., Harada, T., Miyagawa, H., Stefanou, D., Kotzia, G., Efrose, R., Labropoulou, V., Geelen, D., Iatrou, K., Nakagawa, Y., Janssen, C. R., Smagghea, G. and Sweversd, L. (2010). Assessment of species specificity of moulting accelerating compounds in Lepidoptera: comparison of activity between Bombyx mori and Spodoptera littoralis by in vitro reporter and in vivo toxicity assays. J. Pest Manag. Sci., 66: 526-535.

Soltani, N. and Soltani-Mazouni, N. (1992).

Diflubenzuron and oogenesis in the codling moth, Cydia pomonella (L.). Pestic. Sci., 34: 257-261.

Sorge, D., Nauen, R., Range, S. and Hoffmann, K. H. (2000). Regulation of vitellogenesis in the fall armyworm, Spodoptera frugiperda (Lepidoptera: Noctuidae). J. Ins. Phys., 46(6): 969-976.

Tanaka, S., Okuda, T., Hasegwa, E. and Knon, Y. (1998). Suppression of oocyte development by a trehalase inhibitor, validoxylamine $\mathrm{A}$, through inhibition of juvenile hormone biosynthesis and vitellogensis in the migratory locust. Locusta migratoria. Entomol. Sci., 13(3): 313-320.

Tripathi, R. K. (1996). Information sheet on Dimilin.Richmond, Virginia 23218 (804)786-1763.

Zhang, Y. C. And Qi, Y. M. (2008). Histological effect of fenoxycarb on the Oriental rat flea, Xenopsylla cheopis (Siphonaptera: Pulicidae). Acta Entomol. Sinica, 51(5):504-508. 